\title{
Traditional Values and the Problem of Death Sentence in American Mass Media
}

\section{Anna N. Ustinova}

\author{
Institute of Socio-Political Research of the RAS; Email: ustinova.a.n@gmail.com
}

\author{
Doi:10.5901/mjss.2015.v6n5s3p360
}

\begin{abstract}
In the present article we examined the genesis of public opinion in the USA about the death sentence basing on public reaction to the information given on the subject in written and electronic mass media. We placed our close attention on the changes of public opinion in evaluating facts due to ratings of the sources and the influence of certain US mass media. The issues covered in the present article appear not only relevant and valid from politico-social point of view, but are also undoubtedly innovative in two aspects: the global character of presentation of a problem and the specificity of the attained results.
\end{abstract}

Keywords: death sentence, public opinion, mass media, constitutional legislation.

\section{Introduction}

The problem of death sentence was traditionally in the center of public interest. The 1787 Constitution of the United States of America and especially its amendment - The Bill of Rights, connected, ideologically and contextually, the most important American democratic freedoms with their coverage in mass media (Christopher S., 2007). Up to the present day the majority of US population relies on mass media's competence in picking, arranging and presenting information (Frank E. Dardis, Frank R. Baumgartner, Amber E. Boydstun, Suzanna De Boef \& Fuyuan Shen, 2006). Large media corporations of last decades (Walt Disney Company, News Corporation, Time Warner, CBS Corporation, Viacom, NBC Universal и Sony Corporation of America) that control 95\% of traditional mass media are in fact forming the system of values and opinions of Americans on certain social issues (Edward S. Herman \& Noam Chomsky, 1988).

\section{Materials and Methods}

In the function of the main materials the media publication are used, and their comparative study constituted the subject matter of the present article.

According to cable news channels Nielsen ratings Fox News programs (News corporation) O'Reilly factor and Special report with Bret Baier (creator - Sean Hannity) continue in the top ten of the rating. The anchor men of these programs are representatives of the Republican Party who manifest conservative ideas and values of the American society which reflects on their approach to the presentation of news. In particular, we should note a quite tendentious coverage of the death. Republican mass media have always demonstrated more abruptness, intolerance and bias when presenting and commenting on this issue which of course has influenced the viewers. Nevertheless, each one of them has different approach to the interpretation of facts. Thus, Bret Baier has a moderate approach; Sean Hannity, on the opposite, has recently surprised his audience by saying that execution by shooting is a humane alternative to a lethal injection because it excludes improper performance; O'Reilly considers himself more of a traditionalist rather than a conservator and does not share Republicans' view on death penalty, suggesting that it should be replaced with compulsory labour in correctional facilities "such as Gulag" in remote areas (Gabdrafikov, Karabulatova, Khusnutdinova \& Vildanov 2015; Ryazantsev, Karabulatova, Sivoplyasova, Pismennaya \& Manshin 2015; Ryazantsev, Karabulatova, TerAkopov, Pismennaya \& Bozhenko, 2015 \& Ryazantsev, Karabulatova, Mashin, Pismennaya \& Sivoplyasova, 2015), for instance, in Alaska, It is an analogue of the harsh Siberia in the public consciousness (Karabulatova \& Zinchenko, 2014 \& Karabulatova, Fedorova \& Sayfulina, 2014). These remote places away from civilization perceived as a place of power, a place for testing of the spirit (Karabulatova \& Sayfulina 2015; Karabulatova, Ermakova \& Chiganova, 2014 \& Karabulatova\& Akhmetova, 2015). 


\section{Results}

The attained results are based on the consideration of a wide range of views on the research which was carried out.

We should also mention the so-called "reverse effect" of the most popular programs and anchor men (Jeremy Harris Lipshultz, 2002). Here is an example. In 2005 when there was a massive scandal in America related to George Tiller who practiced abortions during late pregnancies, following the spirit and letter of traditional Republican values, Bill O'Reilly carried out a large and long-lasting accusatory campaign against him. He even used an old journalist technique and made up a nickname for Tiller calling him Tiller the Baby Killer. When in May 31, 2009 Tiller was killed during a sabbatical in a Lutheran church in Kansas many people thought that it was a direct consequence of O'Rilley's speeches that have gone too far in demonizing Tiller. At that, many people think that the anchor men intentionally "distort facts in favor of their ideology" and make a murderer new hero for conservators by popularizing his ideas among millions of TVviewers (Justin Baragona, 2014).

Another Fox News presenter Greta van Susteren has repeatedly brought up the issue of death sentence during her live programs. She has legal education and a vast experience in jurisprudence which gave her the opportunity to use this sensitive topic as a vehicle to make some broader comments on US justice in general. Some of her statements are worth mentioning, not least because she considers herself as an intelligent and honest citizen who does not belong to any party. "I do not think the death penalty can be taken lightly or prescribed as carelessly as it is in America today. The death penalty should be a deterrent, and if it is commonplace, if we can't even remember the name of the last person executed in this country, we will forget just how serious it is" (Greta Van Susteren \& Elaine Lafferty, 2003). Justice does not come easily but at the end of the day this is exactly why, in her opinion, Americans stand out among other nations. That is why we should not be looking for easy ways in democracy and then justice will be our reward. Susteren, of course, has her own opinion about criminals, for instance, those who commit deliberate and cruel acts, and about the punishment they should get for these crimes but, nevertheless, she separates her human emotions and personal opinions from impartial state policy and punishment system, rightfully believing that in some cases the state could've sunk to the level of those criminals.

\section{Discussion}

Politico-social aspect of the debated subject is reflected in comparison of the positions of different researches of this global problem.

By giving these examples we inevitably face the question: should we consider commercial success of Republican channels a reason or a consequence of the fact that death sentence still exists in American society, has legal reasoning and jurisdiction despite of all the declarations of the triumph of democracy in the country (Joseph Farah, 2007)? And, moreover, is journalism still a "watchdog of democracy" and political processes or are its main sources targeted at maintaining conservative values and reactionary views?

Answering this question we also inevitably address political aspects of the discussion about death sentence in American mass media because, as the authors of the article Rightwing triumph is called off accurately pointed out, "what can be more pleasant for an editor than giving a momentum to a political discussion? Relevance is the gold standard of mass media" (Malenie Amann, Isabel Husen, Ann-Katrin Mueller \& others, 2014). So we should not be surprised that the institute of death sentence is being paid so much attention in public policy of the United States: no electoral campaign can pass around this issue, and criticism towards the ruling party always includes criticism towards the approach of this party and some of its members towards the question of death sentence (Scott McCabe \& Emily Babay, 2011).

We would like to add that the terrorist attack of September 11, 2001 has caused a massive flow of accusatory information towards public institutes and certain public actors due to the lack of security measures aimed to protect the citizens of America. That persuaded people that existent laws and legal frameworks should be strengthened in order to react more effectively to any acts of violation of public order that result in death of people (Justin Baragona, 2014).

In this situation we can see how the mechanisms, that powerful philosopher, political analytic and public leader Noam Chomsky characterized as mass media manipulation based on the emotions, are working (Noam Chomsky, 1994).

These mechanisms do structured behavior modern person (Karabulatova 2013, p. 795). The modern society participants impose on additional installation of rewards and punishments under the influence of various media. On the one hand, the search for the ideal partner, searching for the ideal person (Karabulatova, 2013, p. 793; Khachmafova, Karabulatova, Luchinskaya \& Osipov 2015; Ostrovskaya, Karabulatova, Khachmafova, Lyaucheva \& Osipov, 2015 \& Karabulatova, Khachmafova, Bricheva, Nescheretova \& Bersirova, 2015). On the other hand, is self-blame and punishment in violation of accepted norms (Ostrovskaya, Karabulatova, Khachmafova, Lyaucheva \& Osipov, 2015; 
Khairullina N.G. \& Karabulatova, 2014 \& Karepova, Karabulatova, Novikov, Klemovitsky, Stratan \& Perova, 2015).

Following his logic we can suggest that American society as a system can deliberately "let the spiral of violence spin in the cities or organize bloody terrorist acts for the citizens to demand adopting the laws that strengthen security measures and carrying out policy that restricts civil freedoms" (http://noam-chomsky.tumblr.com). And manipulating people's emotions is a classic technique aimed at blocking the ability of people to analyze facts rationally and critically. Besides, the use of the emotional factor helps open the doors to the subconscious and plant thoughts, wishes, fears, coercions and behavior models (Edward S. Herman \& Noam Chomsky, 1988).

Noam Chomsky himself believes that "the existence of death sentence can only be tolerated by blatant reactionaries who feel persistent need of a regime so strong that it has the right to kill people" (http://www.goodreads. com). Chomsky consistently points out that the state cannot have the right to take away people's lives and that death penalty is a crime. He fully supports the opinion of Amnesty International and, as he believes, the majority of population of the Earth. Although the story of the murder of Osama bin Laden has proven this theory wrong.

\section{Conclusion}

The perception of death sentence keeps changing along with the principles of discussion on this subject. The book of famous political analysts Frank R. Baumgartner, Suzanna L. De Boef and Amber E. Boydstun (The Decline of the Death Penalty and the Discovery of Innocence, 2008) shows the results of observations that prove that close attention of mass media to the cases, when death sentences have been reconsidered or proven iniquitous, and also when erroneous sentences have been given beginning from the middle of last century, has moved the focus of public opinion from considering only constitutional and financial aspects of capital punishment towards moral aspects.

Negative facts about the practice of death penalty that constantly appear in mass media have played the key role in decreasing the number of capital punishment supporters. This tendency, of course, does not exclude the fact that a large number of Americans still think that death sentence can be considered "morally acceptable" (http://www.gallup.com/ poll/1606/death-penalty.aspx). Nevertheless when considering the aspect of innocence it keeps losing its supporters.

\section{References}

Christopher, S. Kudlac (2007) Public executions: the death penalty and the media. Westport, Conn.: Praeger.

Edward, S. Herman \& Noam, Chomsky (1988) Manufacturing Consent: The Political Economy of the Mass Media. Pantheon Books, New York.

Frank, E. Dardis \& Frank, R. (2006) Baumgartner, Amber E. Boydstun, Suzanna De Boef, Fuyuan Shen. Media Framing of Capital Punishment and Its Impact on Individuals' Cognitive Responses. - Mass Communication and Society, Pennsylvania State University.

Frank, R. Baumgartner, Suzanna, L. De Boef \& Amber E. Boydstun (2008) The Decline of the Death Penalty and the Discovery of Innocence. Cambridge University Press, Cambridge, New York.

Gabdrafikov, I.M., Karabulatova, I.S., Khusnutdinova, L.G., \&Vildanov Kh.S. (2015) Ethnoconfessional Factor in Social Adaptation of Migrant Workers in the Muslim Regions of Russia. In the: Mediterranean Journal of Social Science. Vol 6, No3, Supplement 4, May 2015. pp. 213-223. Doi:10.5901/mjss.2015.v6n3s4p213 http://www.mcser.org/journal/index.php/mjss/article/view/6732/6446

Greta, Van Susteren \& Elaine, Lafferty (2003) My Turn at the Bully Pulpit. - Crown Publishers, New York.

Janet, Malcolm (1990) The Journalist and the Murderer. - Vintage Books, A Division of Random House, Inc., New York.

Jeremy, Harris Lipshultz (2002) Crime and local news: dramatic, breaking and live from the scene. Jeremy H. Lipshultz, Michael L. Hilt (LEA'scommunication series).

Jeremy, Harris Lipshultz (2014) Social Media Communication. Concepts, Practices, Data, Law and Ethics. Routledge, New York.

Joseph, Farah (2007) Stop the Presses! The Inside Story of the New Media Revolution. WND Books, Los Angeles, California.

Justin, Baragona (2014) Sean Hannity Defends Vicious Killer; Is He Trying To Create A New Conservative Folk Hero? Politicus USA, May, 1st.

Ken, Klukowski (2011) American sovereignty and Republican politics in latest Texas execution. The Washington Examiner.

Karabulatova, I.S. (2013) The problems of linguistic modeling of new Eurasian linguistic personality in multilinguistic and mental environment (by example of onomasphere). In the: Middle-East Journal of Scientific Research 17 (6): 791-795. ISSN 19909233.๑ IDOSI Publications, 2013.DOI: 10.5829/idosi.mejsr.2013.17.06.12262. http://www.idosi.org/mejsr/mejsr17(6)13/15.pdf http://www.idosi.org/mejsr/mejsr17\%286\%2913.htm.

Karabulatova, I.S. \& Zinchenko, A.A. (2014) Tyumen Nenets Sacral Childhood Culture as an Ethnolinguistic Mechanism of Preserving Ethnic Identity // Middle-East Journal of Scientific Research 20 (11): 1344-1347. ISSN 1990-9233. (c) IDOSI Publications, 2014.DOI: 10.5829/idosi.mejsr.2014.20.11.21071 http://www.idosi.org/mejsr/mejsr20\%2811\%2914.htm.

Karabulatova, I.S., Fedorova, E.A. \& Sayfulina, F.S. (2014) A Linguo-Mythological Space of the Toponym "Siberia" in Contemporary Slavonic Linguistic Consciousness// World Applied Sciences Journal 30 (9): 1134-1138. ISSN 1818-4952 @ IDOSI Publications, 
2014.DOI: 10.5829/idosi.wasj.2014.30.09.14118 http://www.idosi.org/wasj/wasj30\%289\%2914/9.pdf.

Irina, Sovetovna Karabulatova, Zaineta, Ruslanovna Khachmafova, Madina, Marzakanovna Bricheva, Tamara, Teuchezhevna Nescheretova \& Asya Kazbekovna Bersirova (2015) Linguopragmatic Aspect of "Search for the Ideal" in the Discourse of Female Fiction as a Reflection of Matrimonial-Demographic and Sexual Behavior in Contemporary Russian Society. Review of European Studies. Vol. 7. No 6 (2015). - pp.: 35-45. Received: February 28, 2015 Accepted: March 20, 2015 Online Published: April 24. 2015 doi:10.5539/res.v7n6p35. http://www.ccsenet.org/journal/index.php/res/article/view/47980/25754

Karabulatova, I.S. \& Sayfulina, F.S. (2015) Mytholinguistic Interpretation of Sacral Toponym Astana in Sociocultural Practice of the Siberian Tatars. In the: Asian Social Science. Vol. 11, No 5, pp.: 303-310. http://www.ccsenet.org/journal/index.php/ass/ article/view/45271/24521.

Karabulatova, I.S., Ermakova E.N. \& G.A.Chiganova. (2014) Astana in Kazakhstan and Astana in Siberia as a form of national islam of Eurasia in the linguistic-cultural aspect. In the: Terra Sebus: Acta Musei Sabesiensis, Special Issue. pp. 15-30 http://www. cclbsebes.ro/docs/Sebus_SI_2014/02_ISKARABULATOVA_ENE_GAS.pdf.

Karabulatova, I.S. \& Akhmetova B.Z. (2015) Characteristics of Social-Cultural Vitality of Modern Russian Settlements of the Former Gorky Line of Kazakhstan. In the: Mediterranean Journal of Social Science. Vol 6, No3, S4, May 2015. pp.201-206. http://www.mcser.org/journal/index.php/mjss/article/view/6730/6444.

Svetlana, Gennadievna Karepova, Irina, Sovetovna Karabulatova, Vladimir, Sergeevich Novikov, Sergey, Veniaminovich Klemovitsky, Dmitry, Ivanovich Stratan \& Anastasia, Evgenievna Perova (2015) New Approaches to the Development of Methodology of Strategic Community Planning. In the: Mediterranean Journal of Social Science. Vol 6, No3, S.6. pp.357-364. http://www.mcser. org/journal/index.php/mjss/article/view/6831/6539.

Khachmafova, Z.R., Karabulatova, I.S., Luchinskaya, E.N. \& Osipov G.V. (2015) Gender Features of Discourse of Woman's Literature as a Reflection of Changes in the Modern Society. In the: Mediterranean Journal of Social Science. Vol 6, No3, S.2, May 2015. pp. 476-481. Doi:10.5901/mjss.2015.v6n3s2p476. http://www.mcser.org/journal/index.php/mjss/article/view/6528/6255

Khairullina, N.G. \& Karabulatova I.S. (2014) Bailiff's Social Portrait. In the: Middle-East Journal of Scientific Research 19 (3): $417-420$. ISSN 1990-9233. @ IDOSI Publications, 2014. DOI: 10.5829/idosi.mejsr.2014.19.3.13686 http://www.idosi.org/mejsr/mejsr19\% $283 \% 2914 . h t m$.

Ostrovskaya, T.A., Karabulatova, I.S., Khachmafova, Z.R., Lyaucheva, S.A. \& Osipov G.V. (2015) The Discourse of the Russian Elite in the ERA "Liquid" Modernity as a Problem of Ethnic, Social and Cultural Security. In the: Mediterranean Journal of Social Science. Vol 6, No3, S4, May 2015. pp. 147-154. http://www.mcser.org/journal/index.php/mjss/article/view/6723/6437.

Laura, E. (1997) Randa. Society's final solution: a history and discussion of the death penalty. - University Press of America.

Lipshultz, Jeremy Harris (2002) Crime and local news: dramatic, breaking and live from the scene / Jeremy H. Lipshultz, Michael L. Hilt (LEA's communication series).

Malenie, Amann, Isabel, Husen, Ann-Katrin, Mueller \& others (1994) Rightwing triumph is called off. - Profil.

Noam, Chomsky (1994) Secrets, Lies, and Democracy. Tuscan, The Real Story Series.

Ryazantsev, S.V., Karabulatova, I.S., Sivoplyasova, S.Yu., Pismennaya, E.E. \& Manshin R.V. (2015) Modern Aspects of Human Trafficking in the Context of Labor Exploitation and Irregular Labor Migration in the Russian Federation. In the: Mediterranean Journal of Social Science. Vol 6, No3, S.2, May 2015. pp. 67-72. Doi:10.5901/mjss.2015.v6n3s2p67. http://www.mcser.org/ journal/index.php/mjss/article/view/6465/6195

Ryazantsev, S.V., Karabulatova, I.S., Ter-Akopov, A.A., Pismennaya, E.E. \& Bozhenko V.V. (2015) The specificity of the differential regulation of economic integration in the context of contemporary labor migration. In the: Mediterranean Journal of Social Science. Vol 6, No3, May 2015. pp. 96-102. Doi:10.5901/mjss.2015.v6n3p96. http://www.mcser.org/journal/index.php/mjss/ article/view/6220/5964

Ryazantsev, S.V., Karabulatova, I.S., Mashin, R.V., Pismennaya, E.E. \& Sivoplyasova, S.Yu. (2015) Actual problems of human trafficking in Illegal immigration in the Russian Federation. In the: Mediterranean Journal of Social Science. Vol 6, No3, S.1, May 2015. - pp.: 621-626. Doi:10.5901/mjss.2015.v6n3s1p621. http:/www.mcser.org/journal/index.php/mjss/article/view/6451/6185

Scott, McCabe \& Emily, Babay (2011). Crime and Punishment. - The Washington Examiner.

http://noam-chomsky.tumblr.com.

http://www.goodreads.com.

http://www.gallup.com/poll/1606/death-penalty.aspx. 